\title{
Differensi Energi Hidrostatis Analis sebagai Pengendali Pengaturan Pintu Air
}

\author{
Herdianto, Suharjoko \\ Staft Pengajar Program Studi D-III Teknik Sipil FTSP \\ email: suharjoko_hydro@ce.its.ac.id
}

\begin{abstract}
ABSTRAK
Wilayah kota Surabaya, memiliki thopografi dataran relatif landai, sementara itu porisitas tanahnya relaif kecil sehingga limpasannya menjadi besar. Pemerintah Kota Surabaya telah berupaya menyelesaikan drainase kota Surabaya dengan memperbesar kapasitas drainasenya maupun menekan hidrograf banjirnya, bahkan telah dilakukan dengan mengkombinasikan antara rehabilitasi saluran, pompa, bozem, pintu air, shortcut dan sumur resap serta pengembangan retarding bazin. Namun demikian kenyataan yang terjadi, bahwa banjir di Kota Surabaya masih belum dapat terselesaikan. Hal ini disebabkan banyaknya kendala yang dihadapi dalam pelaksanaannya.

Pada sungai tertentu dimana muaranya berhubungan atau dipengaruhi oleh pasang surut air laut, jika inflow banj ir lebih besar dari pada kapasitas outflow sungai dan terjadi lebih dari 6 jam, maka sistem drainasenya biasanya dilengkapi dengan bozem (storage), pintu air dan pompa. Bozem berperan menampung sementara aliran banjir datang ketika terjadi muka air laut pasang dan akan dikeluarkan ketika air laut surut. Tetapi oleh karena kapasitas bozem yang ada di wilayah kota Surabaya pada umumnya kecil, maka bozem yang ada kebanyakan dilengkapi dengan pompa air. Bahkan realita yang ada di drainase sistem Surabaya bahwa di beberapa tempat di pertemuan saluran sekunder ke saluran primer atau pertemuan saluran drainase tersier ke saluran primer dilengkapi pintu dan pompa yang dikendalikan secara manual. Dan permasalahan banjir diakibatkan karena keteledoran pengoperasian secara manual tersebut.

Dengan demikian masalah yang menjadi perhatian adalah pengoperasian antara pintu air dan pompa, oleh karena itu pentingnya penelitian ini adalah melakukan disain alat sebagai analisa perbedaan energi antara energi hidrostatis di hulu pintu air dengan energi hidrostatis di hilir pintu air, sehingga dapat dipergunakan sebagai pengendalian otomatisasi pengoperasian (switching automatics) terhadap fasilitas drainase seperti yang disebutkan di atas. Sehingga dalam penelitian ini telah dilakukan desain suatu alat yang dapat menangkap energi hidrostatis yang handal dari kedua sisi pintu. Dan melakukan disain alat detector energi analysis sebagai analisa perbedaan energi antara energi hidrostatis di hulu pintu air dengan energi hidrostatis di hilir pintu air.

Disain Detector Energi Hydrostatis ini telah dilakukan tiga kali, yakni yang pertama sistem membran, kedua sistem klep dan yang ke tiga sistem bola. Masing-masing telah diuj i dan masing-masing memberikan kekurangan dan keunggulannya. Rancangan pertama adalah sistem membrane yang menghasilkan hubungan antara tekanan dengan skala yang ditunjuk berbentuk parabolic. Rancangan kedua kurang dapat bekerja dengan baik karena rawan kotor oleh endapan koloid, dan rancangan ketiga adalah sistem bola, sistem bola ini bekerja cukup baik dan menunjukkan hubungan antara tekanan dengan skala yang ditunjuk berbentuk linier. Dan setelah dilakukan pengujian dan dengan pertimbangan maksud penelitian ini maka Detector Energi Hydrostatis sistem bola memiliki lebih banyak keunggulan. Bahkan telah dapat diuji dan dikembangkan sebagai alat pengamatan pasang surut muka air laut dengan validitas hasil yang cukup baik.
\end{abstract}

Keyword : Difference Energy analysis, Detector Energy Hydrostatis, Pintu air.

\section{PENDAHULUAN}

\subsection{Latar Belakang}

Wilayah kota Surabaya, memiliki Thopografi dataran relatif landai sementara itu susunan tanahnya terdiri atas lanau dan muka air tanahnya dangkal, sehingga porisitasnya relaif kecil, dengan demikian limpasannya menjadi besar. PemerintahKota Surabaya telah berupaya menyelesaikan drainase kota 
Surabaya dengan memperbersar kapasitasnya maupun menekan hidrograf, bahkan telah dilakukan dengan mengkombinasikan antara rehabilitasi saluran, pompa, bozem, pintu air, shortcut dan sumur resap serta pengembangan retarding bazin. Namun demikian kenyataan yang terjadi, bahwa banjir di Kota Surabaya masih belum dapat terselesaikan. Hal ini disebabkan banyaknya kendala yang dihadapi dalam pelaksanaannya.

Pada sungai tertentu dimana muaranya berhubungan atau dipengaruhi oleh pasang surut air laut, jika inflow banjir lebih besar dari pada kapasitas outflow sungai dan terjadi lebih dari 6 jam, maka sistem drainasenya biasanya dilengkapi dengan bozem (storage), pintu air dan pompa. Bozem berperan menampung sementara aliran banjir datang ketika terjadi muka air laut pasang dan akan dikeluarkan ketika air laut surut. Tetapi oleh karena kapasitas bozem yang ada di wilayah kota Surabaya pada umumnya kecil, maka bozem yang ada kebanyakan dilengkapi dengan pompa air. Bahkan realita yang ada di drainase sistem Surabaya atau yang direncanakan sesuai dengan arahan masterplan drainase (SDMP, 1999), bahwa di beberapa tempat di pertemuan saluran sekunder ke saluran primer atau pertemuan saluran drainase tersier ke saluran primer direncanakan dilengkapi pintu dan pompa. Berdasarkan uraian diatas, masalah yang menjadi perhatian adalah pengoperasian antara pintu air dan pompa, oleh karena itu pentingnya penelitian ini adalah untuk mendapatkan suatu alat otomatis sebagai pengendali operasi antara pintu air dan pompa yang biasa terdapat di suatu bangunan bozem. Pengoperasian pintu air dan pompa dipertimbangkan terhadap adanya perbedaan muka air di hilir dan di sungai. Pada Gambar 1, ditunj ukkan kedudukan pompa dan pintu air pada pertemuan sungai / bozem dengan laut atau sungai.

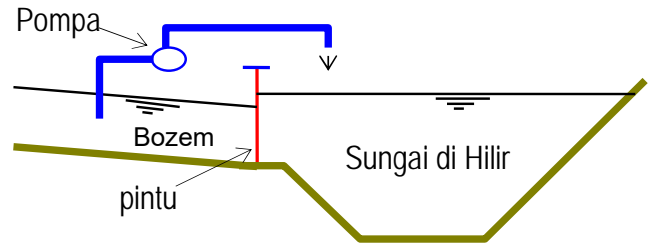

Sket Pertemuan bozem dengan Sungai

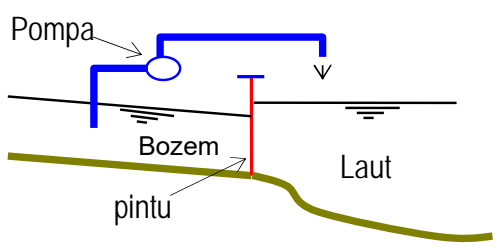

Sket Pertemuan bozem dengan Laut

Gambar 1: Kedudukan pompa dan pintu air pada pertemuan bozem dengan sungai atau dengan laut

Di Surabaya terdapat banyak pintu-pintu bozem menggunakan pintu sorong dengan pengendaliannya secara manual dan pada kasus tertentu yakni jika kapasitas bozem kecil, dilengkapi dengan pompa.

Namun permasalahannya adalah karena pada otomatisasi operasional pintu diganti dengan tenaga manusia, maka memberikan kemungkinan kerawanan keteledoran atau kealpaan, untuk mengatasi hal ini perlu pengembangan otomatisasi pengoperasian pintu dan pompa. Beberapa ilmuwan telah mengembangkan otomatisasi pengoperasian dengan memanfaatkan perbedaan muka air. Perbedaan muka air tersebut merupakan indicator penentu otomatisasi. Sensor optic maupun sensor micro wave harganya cukup mahal, dan hal lain yang memberatkan adalah sensor tersebut harus dipasang di bagian atas permukaan, bentuknya bagus dan menarik sehingga dengan kondisi ini menjadi rawan hilang akibat kecurian. Sementara itu prinsip dasar pengaliran adalah adanya perbedaan energi hidrostatis, bukan perbedaan muka air.

Penelitian ini akan mengembangkan pemanfaatan perbedaan energi hidrostatis antara di belakang dan di depan pintu air sebagai indicator pengendalian operasi pintu dan pompa. Perbedaan energi hidrostatik 
antara di hulu dan di hilir pintu menjadi hal penting dalam penelitian ini. Pengendalian operasi dalam penelitian ini adalah identik dengan suatu operasi switching (saklar) on atau off pada saklar pintu atau saklar pompa.

\subsection{Perumusan Masalah}

Permasalahan yang menjadi pehatian dalam penelitian ini adalah;

- Bagaimana menangkap energi hidrostatik yang peka terhadap perubahan muka air.

- Bagaimana memanfaatkan perbedaan energi yang terjadi antara di hilir dan di hulu pintu air ( differensi energi hydrostatis ) sebagai pengendali otomatis yang handal.

\subsection{Maksud dan Tujuan}

Maksud penelitian ini adalah untuk mendapatkan salah satu upaya penyelesaian banjir melalui otomatisasi pengoperasian pintu dan pompa secara tepat dan pasti sesuai indicator perbedaan energi hidrostatis yang terprogram sesuai dengan harapan. Sehingga permasalahan banjir akibat dari kesalahan keteledoran pengoperasian pintu dan pompa ini dapat terselesaikan.

Sedangkan tujuan penelitian ini adalah melakukan desain suatu alat yang dapat menangkap energi hidrostatis yang handal dari kedua sisi pintu (detector energi hydrostatis). Dan melakukan disain alat sebagai analisa perbedaan energi antara energi hidrostatis di hulu pintu air dengan energi hidrostatis di hilir pintu air, sehingga dapat dipergunakan sebagai pengendalian otomatisasi pengoperasian (switching automatics) terhadap fasilitas drainase seperti yang disebutkan di atas.

\section{TINJ AUAN PUSTAKA}

\subsection{Studi Kepustakaan}

Pada sekitar tahun 1996, Dinas Pengendali Banjir Surabaya pernah menggunakan alat pengendali otomatis dengan menggunakan sensor optik pada pintu bozem Kalidami, prinsip kerja sensor ini memanfaatkan sinar pantul yang ditimbulkan optik terhadap muka air yang kemudiam diolah sedemikian secara elektrik sehingga dapat menunj ukkan elevasi muka air. Perbedaan muka air antara di hulu dengan di hilir pintu yang ditangkap sensor tersebut dimanfaatkan sebagai indicator pengendali otomatis. Alat ini berjalan dengan baik, namun terdapat kendala social karena sensor hilang dicuri orang. Selain itu, indictor penentu sebagai pengendali otomatis pada alat ini adalah perbedaan muka air pada kedua sisi, tetapi perlu difahami bahwa pada keadaan dimana pada kedua sisi mempunyai berat volume air yang sama, alat tersebut akan bekerja dengan baik, namun jika terjadi berat volume berbeda seperti yang terjadi pada bozem di dekat pantai maka alat tersebut kurang efektif. Disamping itu pula peralatan tersebut sangat mahal sehingga rawan hilang.

Suharjoko (1987), membangun model pintu klep dengan engsel diatas, dari hasil analisa yang didapat pintu dapat bergerak dengan baik secara otomatis, namun pengaliran yang terjadi menunjukkan masih terjadi kontraksi yang cukup besar akibat berat pintu itu sendiri. Berdasarkan hasil analisa di atas, penelitian tersebut dikembangkan dengan mengkaji pintu klep dengan pemberat pada perpanjangan Ienannya sebagai counter weight untuk memperkecil momen. Namun demikian seperti yang disinggung di atas bahwa pintu klep ini sering terjadi permasalahan pada engselnya yakni korosi. Oleh karena itu pada saat ini telah dikembangkan pintu sorong elektrik yang dikendalikan secara manual.

Surabaya Drainage Mastreplant Project (SDMP) 2018, terdapar 12 buah pintu drainage, 6 buah diantaranya pintu klep vertical dan horizontal, namun dari keenam tersebut yang dapat beroperasi hanya 3 buah yang masih baru, kerusakan terjadi pada engselnya dan tidak bersih dari sedimen dan sampah. Akibat dari keadaan ini tidak dapat menutup dengan rapat dan tidak dapat membuka dengan baik. 


\section{MANUFAKTURING PROTOTIPE \& PENGUJ IAN}

3.1. Manufakturing dan Pengujian

3.1.1. Manufakturing dan Pengujian Detector Energi Hidrostatis

Manufakturing dan disain Detector Energi Hydrostatis ini telah dilakukan tiga kali, yakni yang pertama sistem membran, kedua sistem klep dan yang ke tiga sistem bola. Dari hasil pengamatan didapat bahwa Detector Energi Hidrostatis sistem bola merupakan pilihan yang baik untuk dkembangkan (Herdianto 2002).

\section{Detector Sistem Bola}

a. Manufakturing

Pengembangan berikutnya adalah digunakan membrane berbentuk bola dengan harapan dapat mengalami perubahan yang begitu fleksibel mengikuti tekanan yang terjadi terhadap detector. Setelah dirakit dan dilakukan percobaan untuk diuji kemampuannya menunjukkan hasil yang sangat memuaskan.

\section{b. Pengujian alat detector energi}

Proses pengujian akan dilakukan sebagai berikut :

Detector energi setelah dirakit dihubungkan dengan manometer, kemudian dimasukkan ke dalam bak berisi air, posisi detector dibuat tetap namun tinggi air di atas detector dirubah dalam beberapa variasi.

Dari hasil percobaan menunjukkan perubahan antara tekanan hidrostatis dengan skala manometer yang ditunjuk menghasilkan hubungan yang linier. Hubungan yang menunjukkan hasil percobaan detector energi sistem bola tersebut dapat dilihat pada Gambar 2 berikut
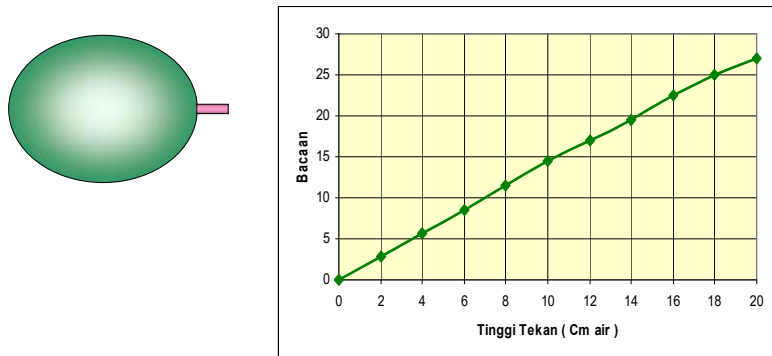

Gambar 2 : Sketsa model detector system bola dan hasil pengujian di laboratorium

\subsubsection{Manufakturing dan Pengujian Analisis Defferensi Energi}

Sama halnya dengan manufakturing Detector Energi Hidrostatis, manufacturing Alat Analis Differensi Energi inipun mengalami pengembangan dari konsep awal yang telah ditawarkan dalam proposal. Yaitu dari awalnya sistem klep kemudian dikembangkan menjadi sistem pegas. Dibawah ini akan diuraikan Analisis Differensi Energi Sistem Pegas.

1. Analisis Differensi Energi Sistem Pegas a. Manufakturing

Pengembangan berikutnya adalah menggunakan sistem pegas yang digerakkan oleh pelampung, sedangkan pelampung tersebut bergerak setelah menangkap indikasi dari kedua detector energi. Untuk membangun alat in maka disiapkan beberapa komponen sebagai ditunjuk pada gambar berikut:

a) Switching

b) Tabung sebagai penangkap energi dari detector .

c) Tabung sebagai penangkap energi dari detector yang dirangkai dengan pilar sebagai sendi.

d) Pelampung yang dirangkai pada kedua ujung tuas.

Pelampung berfungsi sebagai penerima energi dari detector hidrostatis. Kemudian agar dapat dilakukan analisa perbeaan energinya dari kedua sisi, maka didisain suatu tuas dengan sendi di tengah sehingga kedua lengannya sama panjang. Kedua uj ung tuas masing-masing akan menerima terusan energi dari kedua detector energi hidrostatis melalui gerakan pelampung pada masingmasing tabung. Dengan demikian jika terjadi perbedaan energi dari kedua detector yang dimaksud maka tuas akan bergerak berputar menyesuaikan kesetimbangannya. Pergerakan tuas ini meunjukkan adanya perbedaan energi hidrostatis dari kedua sisi. Dengan pergerakan tuas ini dimanfatkan untuk merubah posisi saklar (switching) menjadi terhubung (ON) atau seabaliknya, sehingga dapat dimanfaatkan sebagai media untuk menyambung atau memutus ( conect or disconect ) saklar elektrik motor pintu atau motor pompa pada suatu bozem. Konsep semacam ini adalah disain Analisis Differensi Energi yang merupakan alat 
pengendali pengaturan pintu banjir sebagai pengembangan sistem Klep setelah diketahui bahwa rancangan Sistem klep terdapat kelemahan dalam masalah faktor pengaliran (Herdianto, Suharjoko 2006).

$>$ Susunan Alat Analis Differensi Energi

Dua buah tabung sebagai penangkap energi dari detector diposisikan pada kedudukan yang datar satu sama lain dengan jarak tertentu dan kemudian dirangkai dengan pilar di tengah antara kedua tabung tersebut yang akan difungsikan sebagai perletaan sendi dari tuas tersebut. Tuas ini mempunyai lengan yang sama panjangnya dan pada kedua ujungnya dirangkai dengan suatu batang yang merupakan penerus perubahan kedua palampung yang ditimbulkan akibat perubahan muka air di dalam tabung. Fungsi tuas ini sebagai analisa perbedaan muka air (differensi analis) yang terjadi di antara kedua tabung tersebut. Sedangkan perubahan muka air di dalam kedua tabung adalah sebagai akibat adanya perbedaan energi hidrostatis yang terjadi.

Gerakan tuas tersebut dimanfaatkan sebagai penggerak saklar (switching) arus listrik menuju pompa atau penggerak pintu dapat terhubung. Namun pada kesempatan pengujian di laboratorium ini, tehubungnya arus listrik ditandai dengan lampu let yang menyala.

Tabung sebagai penangkap energi dari detector, dihubungkan dengan detector energi melalui media slang plastik yang berisikan fluida. Fluida yang digunakan dalam hal ini adalah air. Pada Gambar 8. dapat dilihat rangkaian alat differensi analis dengan detector energi, yang sudah siap diuji.

b. Pengujian

Kedua detector energi dirakit pada alat analisis differensi energi untuk mendapatkan pengaturan (setup) alat. Kedua alat detector energi tersebut dimasukkan kedalam dua bak dari kaca agar dapat dilihat perbedaan muka airnya (lihat Gambar 9). Setelah kedua alat detector dipasang pada posisi yang benar, kedua bak diisi dengan air dengan muka air yang berbeda, kemudian pada bak dengan muka air lebih rendah, secara berangsur-angsur ditambah air sampai muka airnya melebihi muka air di bak yang lain. Pengamatan dilakukan dengan mecatat perbedaan muka air antara kedua bak bersamaan dengan mengamati kerja konektor, kerja konektor dapat ditera dengan lampu led. Gambar 10. berikut, menunjukkan kerja pengujian alat analisis differensi energi.

Hasil pencacatan percobaan tersebut dapat dilihat pada Tabel 2. Dari tabel tersebut menunjukkan bahwa setelah mencapai perbedaan muka air $\pm 4 \mathrm{~cm}$, alat differensi analisis telah dapat menggerakkan swiching dengan baik.

\subsection{Analisa Hasil}

\subsubsection{Analisa Alat Detector Energi Hydrostatis}

Detector energi sistem bola ini pada prinsipnya adalah pengembangan sistem membran. Hanya saja membran yang digunakan tidak dibentang mendatar tetapi membran tersebut dibentuk mirip bola. Sehingga kemampuan berubah mengempis atau mengembang lebih leluasa. Dari hasil uj i laboratorium telah menunjukkan kerja yang baik dimana dapat menunjukkan hubungan antara energi hidrostatis dengan skala energi adalah sebanding (mendekati linier), bahkan telah diuji lapangan untuk mengukur pasang surut muka air laut dengan hasi yang memuaskan. Dengan demikian detector energi sistem bola ini yang merupakan hasil akhir penelitian ini.

\subsubsection{Analisa Alat Analis Differensi Energi}

Analis Differensi Energi sistem pegas merupakan pengembangan terakhir dalam penelitian ini. Sistem ini cukup baik dan dapat memberikan analisis yang baik antara perbedaan energi yang terjadi. Alat Analis Differensi Energi Hidrostatis ini dimanfatkan untuk merubah posisi saklar (switching) menjadi terhubung (ON) atau seabaliknya, sehingga dapat dimanfaatkan sebagai media untuk menyambung atau memutus ( conect or disconect ) saklar elektrik motor pintu atau motor pompa pada suatu bozem. Dengan demikian dengan dihasilkannya alat Analisis Differensi Energi, maka otomatisasi pengendalian pintu air dan pompa pada suatu bozem telah dihasilkan. 


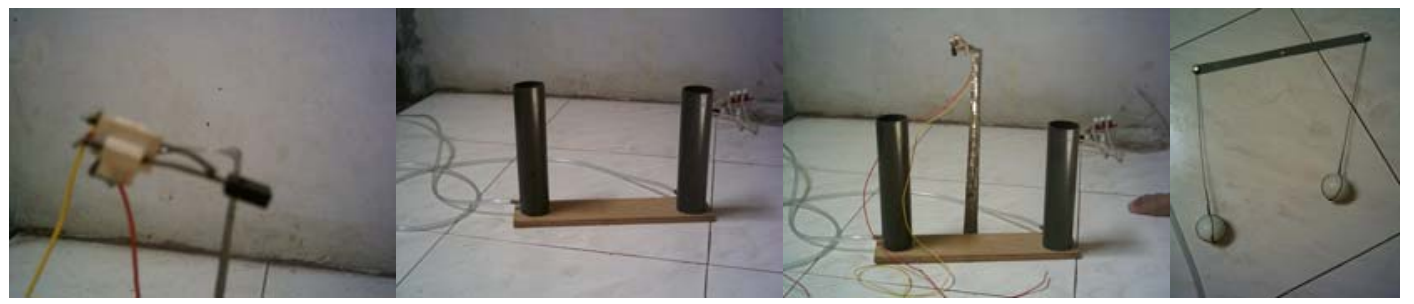

Gambar 6 : Beberapa komponen sebagai alat differensi analisis.

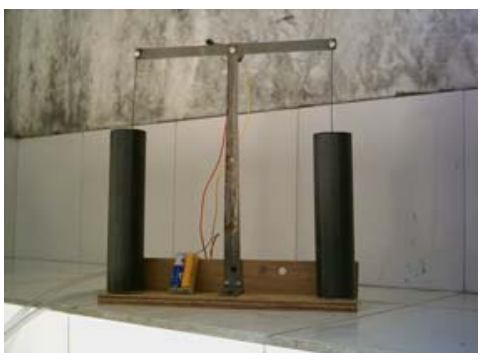

Gambar 7 : Differesi Analis, Kedua tabung sebagai penangkap energi dari detector dirangkai dengan tuas dan pilar sebagai tempat kedudukannya engsel.
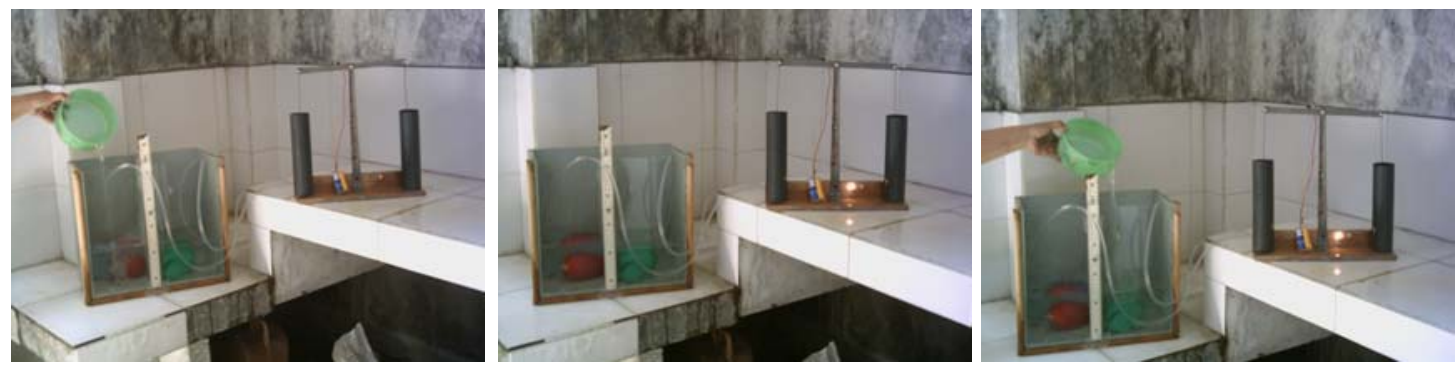

Gambar 10 : Tahapan pengujian dengan pengisian air sehingga memperoleh perbedaan muka air kemudian menggerakkan tuas hingga terjadi connecting (tersambung) yang ditunjuk dengan lampu signal menyala.

Tabel 2 : Hasil pengamatan kerja Diffetrensi Analisis Sistem Pegas

\begin{tabular}{|c|c|c|c|l|}
\hline No. & $\begin{array}{c}\text { Muka air di bak detektor } \\
\text { energi merah }\end{array}$ & $\begin{array}{c}\text { Muka air di bak detektor } \\
\text { energi Hijau }\end{array}$ & Perbedaan muka air & \multicolumn{1}{|c|}{$\begin{array}{c}\text { Keadaan } \\
\text { Lampu Led }\end{array}$} \\
\hline & $(\mathrm{cm})$ & $(\mathrm{cm})$ & $(\mathrm{cm})$ & \\
\hline 1 & 10 & 10 & 0 & mati \\
\hline 2 & 12 & 10 & 2 & mati \\
\hline 3 & 13 & 10 & 3 & mati \\
\hline 4 & 13.5 & 10 & 0 & menyala \\
\hline 5 & 14 & 14 & 1 & mati \\
\hline 6 & 15 & 14 & 2 & mati \\
\hline 7 & 16 & 14 & 3 & mati \\
\hline 8 & 17 & 14 & 4 & Menyala \\
\hline 9 & 18 & 14 & 5 & menyala \\
\hline 10 & 19 & 14 & & \\
\hline
\end{tabular}




\section{ISSN. 1907-753X}

\section{KESIMPULAN}

Dalam penelitian ini telah dilakukan desain suatu alat yang dapat menangkap energi hidrostatis yang handal dari kedua sisi pintu (detector energi hydrostatis). Dan melakukan disain alat sebagai analisa perbedaan energi antara energi hidrostatis di hulu pintu air dengan energi hidrostatis di hilir pintu air.

Disain Detector Energi Hydrostatis ini telah dilakukan tiga kali, yakni yang pertama sistem membran, kedua sistem klep dan yang ke tiga sistem bola. Masing-masing telah diuji dan masing-masing memberikan kekurangan dan keunggulannya. Dan setelah dilakukan pengujian dan dengan pertimbangan maksud penelitian ini maka Detector Energi Hydrostatis sistem bola memiliki lebih banyak keunggulan. Bahkan telah dapat diuj i dan dikembangkan sebagai alat pengamatan pasang surut muka air laut dengan validitas hasil yang cukup baik.

Manufacturing Alat Analis Differensi Energi Hidrostatis mengalami pengembangan dari konsep awal, yaitu dari awalnya sistem klep kemudian dikembangkan menjadi sistem pegas.

Pengembangan berikutnya adalah sistem pegas. Sistem ini cukup baik dan dapat memberikan analisis yang baik antara perbedaan energi yang terjadi. Alat Analis Differensi Energi Hidrostatis ini dimanfaatkan untuk merubah posisi saklar (switching) menjadi terhubung (ON) atau seabaliknya, sehingga dapat dimanfaatkan sebagai media untuk menyambung atau memutus ( conect or disconect ) saklar elektrik motor pintu atau motor pompa pada suatu bozem. Dengan demikian dengan dihasilkannya alat Analisis Differensi Energi, maka otomatisasi pengendalian pintu air dan pompa pada suatu bozem telah dihasilkan.

\section{DAFTAR ACUAN}

Surabaya Drainage Masterplant Project (SDMP), 2000, Final Report, Dinas Pengendalian Banjir Kota Surabaya.

Dinas Pengendali Banjir, 2004, Laporan Tahunan Program Kerja Dinas Pengendalian Banjir.

Suharjoko, 1987, Model Pintu Air Klep dengan engsel diatas, Lembaga Penelitian ITS.

Herdianto, Suharj oko 2006, Rancang Bangun Defferensi Hidrostatis Analisis sebagai Pengendali Mutu Air Bozem, penelitian TPSDP D3 Teknik Sipil, 2006. 